\title{
Digital version of the Rapid Automatized Naming (RAN): a contribution to early detection of reading problems in children
}

\author{
Davino Silva Junior ${ }^{1}$ \\ https://orcid.org/0000-0003-1649-9814 \\ Luciana Cidrim ${ }^{1}$ \\ https://orcid.org/0000-0002-7503-7508 \\ Antonio Roazzi ${ }^{2}$ \\ https://orcid.org/0000-0001-6411-2763 \\ Francisco Madeiro' \\ https://orcid.org/0000-0002-6123-0390
}

Universidade Católica de Pernambuco UNICAP, Recife, Pernambuco, Brasil

2 Universidade Federal de Pernambuco UFPE, Recife, Pernambuco, Brasil

Research support source: Coordenação de Aperfeiçoamento de Pessoal de Nível Superior - CAPES.

Conflict of interests: Nonexistent

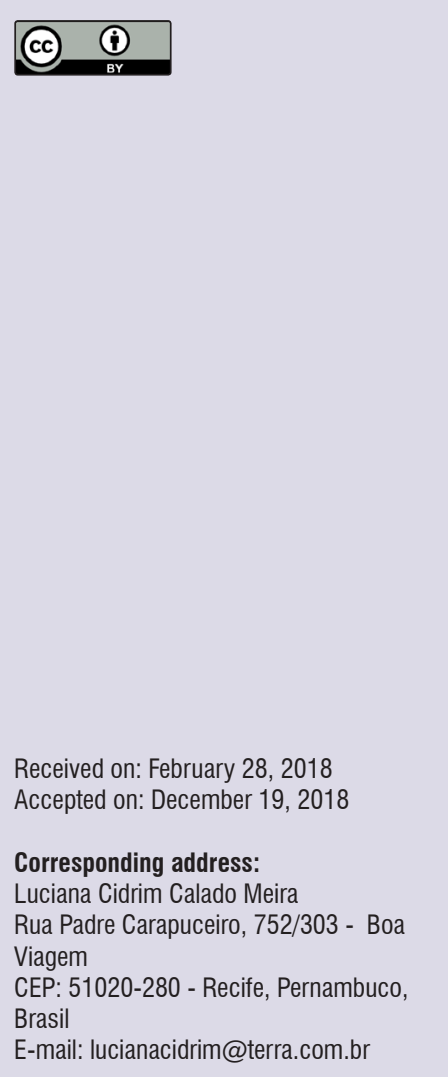

\section{ABSTRACT}

Purpose: to present a digital version of the Rapid Automatized Naming (RAN) test, designed to be used as an auxiliary tool for early detection of reading problems in children.

Methods: the application was designed to provide resources, such as: a) registration; b) information security with the online authentication system - individuals are only seen by the person who registered them and, c) history of the results. In order to know the impressions of speech therapists and professionals of children's education area about this digital version of RAN test, a public opinion survey was conducted with unidentified participants by Google Forms.

Results: the application has an automatic speech recognition and allows registering and accessing the history of the application, including statistical evaluation of the results. The application features a responsive interface that adapts to the dimensions of the mobile device with soft colors, and offers a variety of text font options. The images of the objects of the digital version were elaborated by a designer.

Conclusion: the application presents itself as a useful digital tool that assists professionals to evaluate, early, children with reading difficulties, highlighting the following elements: exclusive and appropriate images to children's universe and the function of storing the results of users tested.

Keywords: Reading; Learning; Technology 


\section{INTRODUCTION}

Reading involves a variety of processes that begin with the visual identification of letters and go as far as understanding the content and context of the written word $^{1-5}$. The reading activity is a complex process, and children who present learning disorders, such as dyslexia, are the ones that suffer the most to fit in the school environment ${ }^{1,3}$.

Dyslexia is a learning disorder of neurological origin characterized by difficulties with fluency and word recognition in reading, as well as problems with decoding and spelling skills ${ }^{6,7}$. As a specific learning disorder, it affects the recognition of words in reading, spelling and writing resulting from a deficit in phonological processing ${ }^{1}$.

In several national and international studies, perceptual, linguistic and cognitive processes involved in reading has been highlighted ${ }^{8-12}$. Researchers have been investigating assessment procedures to verify the use of skills such as phonological awareness, working memory and rapid naming in populations of proficient readers or with alterations in the learning process in reading ${ }^{11,13,14}$. One of the most studied phonological processing skills has been the rapid naming ${ }^{10}$. The naming speed of stimuli is closely related to the speed of access to short-term memory and to phonological naming, which directly influence the development of reading and writing ${ }^{8,15}$.

It is known that children with dyslexia, for the most part, exhibit poor performance in schools' activities, as well as psychoemotional and behavioral problems, such as low self-esteem ${ }^{16}$. In terms of learning, therefore, dyslexia can have an impact on school performance, with all the resulting consequences, and may even lead to dropping out of school. Reading slowly may indicate a deficit in the acquisition of phonological skills and low functioning short-term or operational memory, which makes it difficult to understand the text, since the reader's attention is focused only on the decoding of words, and not the processing of information ${ }^{3}$. Schoolchildren with dyslexia have phonological deficits that make their reading less automatic, slower, requiring more and more effort?

The need to diagnose dyslexia early is thus evident in order to, once identified, have an intervention sufficiently capable of minimizing the symptoms faced by the child. Early detection can be done by means of tests used as predictors of reading ${ }^{17}$. An example of such methods, discussed in the present work, is the Rapid Automatized Naming (RAN) ${ }^{18}$. The RAN test measures the speed in the sequential naming of stimuli, that is, the speed at which the child sequentially names symbols (colors, letters, digits, or objects) distributed randomly, traditionally on a card or sheet of paper. The performance in the test is then compared to standardized values according to the child's age and educational level, values collected from the application of the aforementioned test in groups of children without any difficulties with reading.

With the improvement and widespread use of information and communication technologies (ICTs), in particular of smartphones and tablets, in the rehabilitation of individuals with language and/or learning difficulties $^{19-21}$, it is natural that tasks previously performed with the use of resources such as paper and pen be replaced by applications aimed at mobile devices, thus, simplifying the accomplishment of the tasks in question.

The main objective of this work is to present the construction of a digital version of the RAN test for the Android platform to be used as a simple, modern and easy-to-use auxiliary tool for professionals involved in the area of children's learning, among them, speech therapists, and pedagogues. The work also aims to apply a public opinion survey to know the impressions of speech therapists and education professionals about the digital version of the RAN test.

\section{METHODS}

This study contemplates the development of an application. This digital version of the RAN test was evaluated through a public opinion survey with unidentified participants. Therefore, it was not necessary to submit it to the Research Ethics Committee.

The application was produced for the Android platform using the Integrated Development Environment (IDE) Android Studio with the Software Development Kit (SDK) in version 25. The application was developed based on standards widely used in the area of software development such as Gang of Four (GOF) ${ }^{22}$ design standards, as well as best practices for the development of mobile applications in general, such as the reuse of visual components and the encryption of sensitive data (e.g. audio recorded in the test).

The choice of platform is due to the fact that it is constituted $85 \%$ of the smartphones present in the market ${ }^{23}$ and $68 \%$ of tablets ${ }^{22}$, combining low cost to more and more accessible devices.

Services such as Firebase and Google Speech Application Programming Interface (API) were used 
to offer a form of follow-up of the profile by the professional examiner, as well as to enable the automatic recognition of words (speech recognition) from the recorded audio in the RAN test. In-app tests were conducted with Asus Zen-fone 2 and Samsung Galaxy S4 handsets, containing Android 5 (Lollipop) and 6 (Marshmallow) versions respectively. The application uses appropriate usability standards, adapting the layout components according to different screen sizes of the user's smartphone. In addition, the application has been developed with state-of-the-art technologies such as Firebase, which provides a fast response time during use, for example, when loading profiles of users who have already used the application.

The database used is maintained in the cloud using the infrastructure provided by Google through Firebase. The platform was chosen because it enables the storage and synchronization of data between users and devices in real time with NoSQL database hosted in the cloud. Data is synced across all connected devices and remains available if the application goes offline, providing a better user experience.

The application features a responsive interface that adapts to mobile device dimensions, soft colors and the following textual font options: Arial, Calibri, Times New Roman and OpenDyslexic ${ }^{24}$.

The stimuli presented in the color, number, and letter categories are the same as in the printed version of Denckla and Rudel (1976), except the category objects. The images of the objects presented in this digital version of the RAN test were elaborated by a designer and had their use in the application duly authorized. Some objects used in the application differ from those available in the traditional version of RAN, and are images created in the universe of children: dog, ball, doll, pan and scissors, which ensures familiarity for children without compromising the test.

The application was designed to provide resources to the professional examiner, such as: a) register of individuals to be tested, including name, age, schooling and gender, as well as information of the person in charge; b) information security of the information to the examiner with the use of an online authentication system - each individual is only visualized by the person who registered them, in this case, the professional examiner; c) history of results (such as total time of naming, time of naming by stimulus, number of correct answers, number of errors) of the individual tested, offering the examiner the chance to revisit the tests performed. The application also has an automatic speech recognition and allows registration and access to the application history of the test, including statistical evaluation of results obtained.

From a previous study on applications aimed at dyslexic children ${ }^{25-28}$, a graphical interface was elaborated with elements such as: soft colors by means of shades of blue, text font for children with dyslexia and dimensions suitable for buttons and textual fields on the screen. Dyslexic children perform better when submitted to blue filters and softer contrasts ${ }^{29}$.

\section{RESULTS}

The application has a login screen for the professional examiner, who can create an account if it is the first access, informing name, email and password. The application allows one to request recovery and reset the password. The graphical interface of the application was elaborated from a blue color palette for menus and base buttons, as shown in the screen for choosing the variation of the RAN test, shown in Figure 1. 


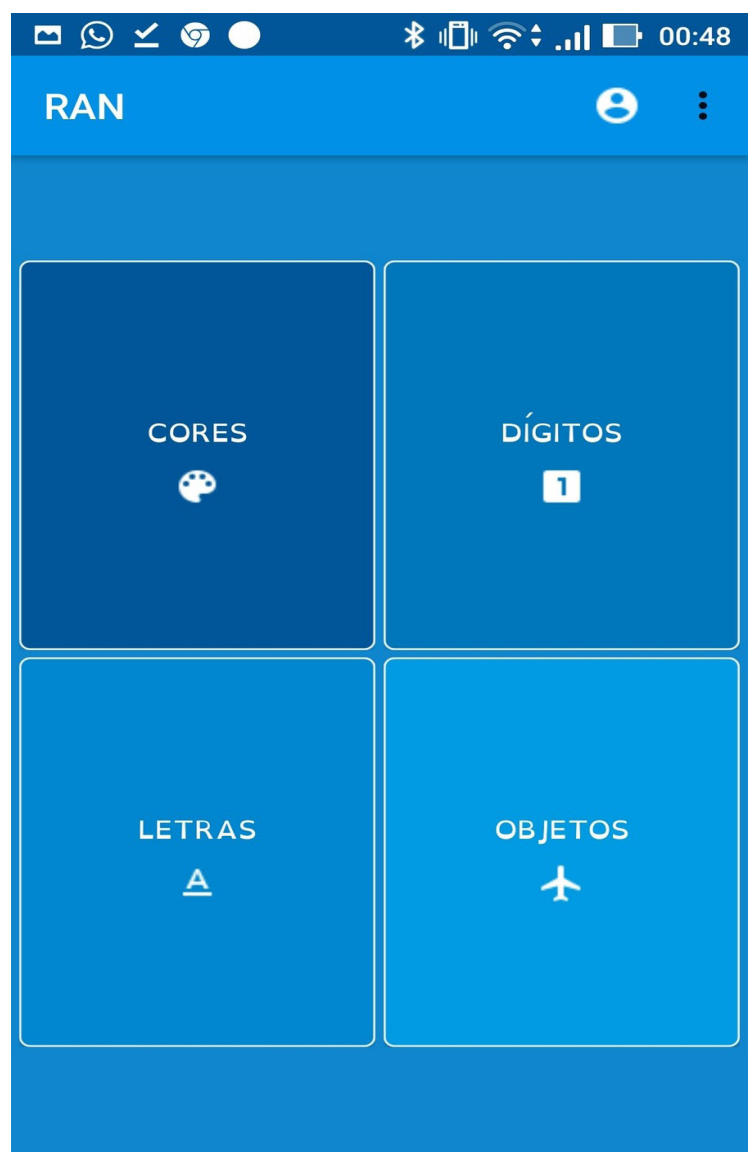

Figure 1. Menu options for the test to be performed

The initial authentication stream is the entry point of the application. The soft colors, using a palette of colors in blue, follow the premise of making the application a pleasant experience, not only for the target public of dyslexic children, but also for children without suspected dyslexia, to evaluate other reading problems such as difficulties in the literacy process.

Once logged in, the application displays a list of users previously registered by the examiner, who can create, edit, or remove a user. The user creation form includes mandatory fields such as name, age, schooling, and gender, in addition to the data of the person responsible for the child.

The digital version of the test can be started by selecting any user in the list and accessing the user edit screen (Figure 2) by entering the "start test" button.

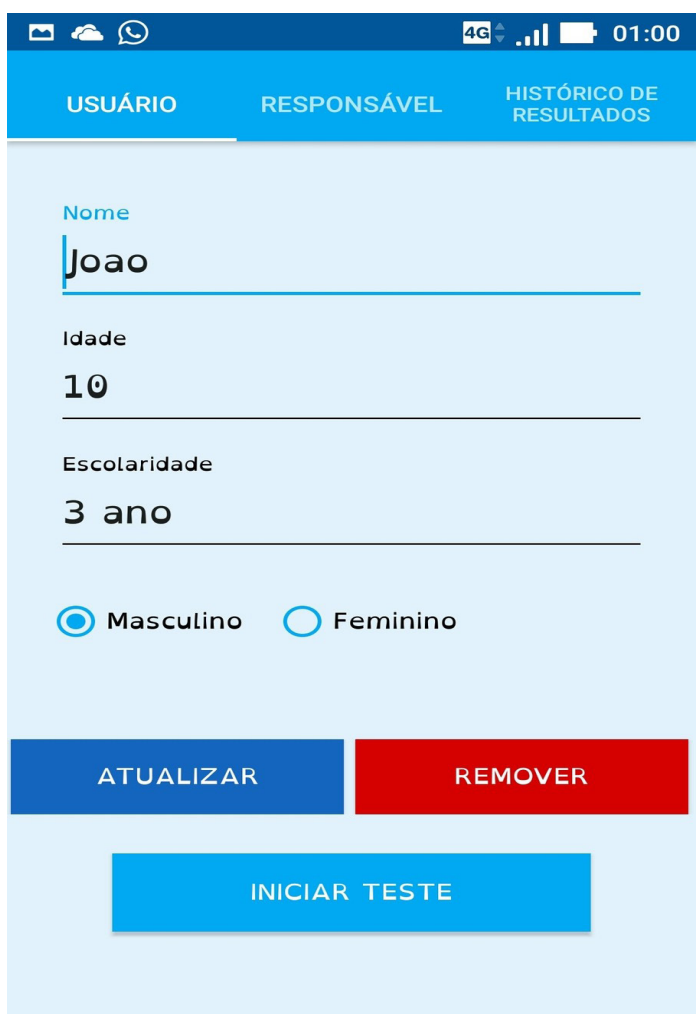

Figure 2. User edit screen

Once the test option is selected, the stimuli to be named by the child are presented. Figures 3, 4, 5 and 6 present, respectively, variations of colors, digits, letters and objects.

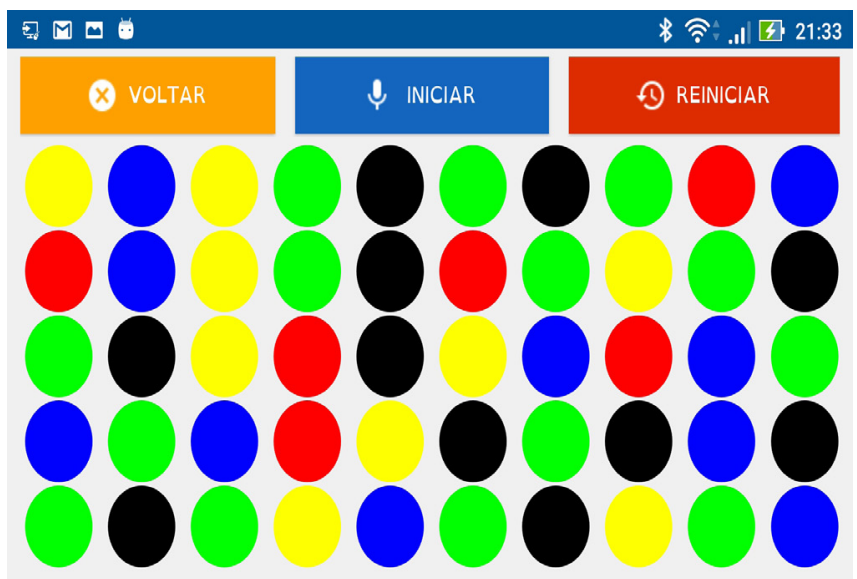

Figure 3. Test screen (colors) 


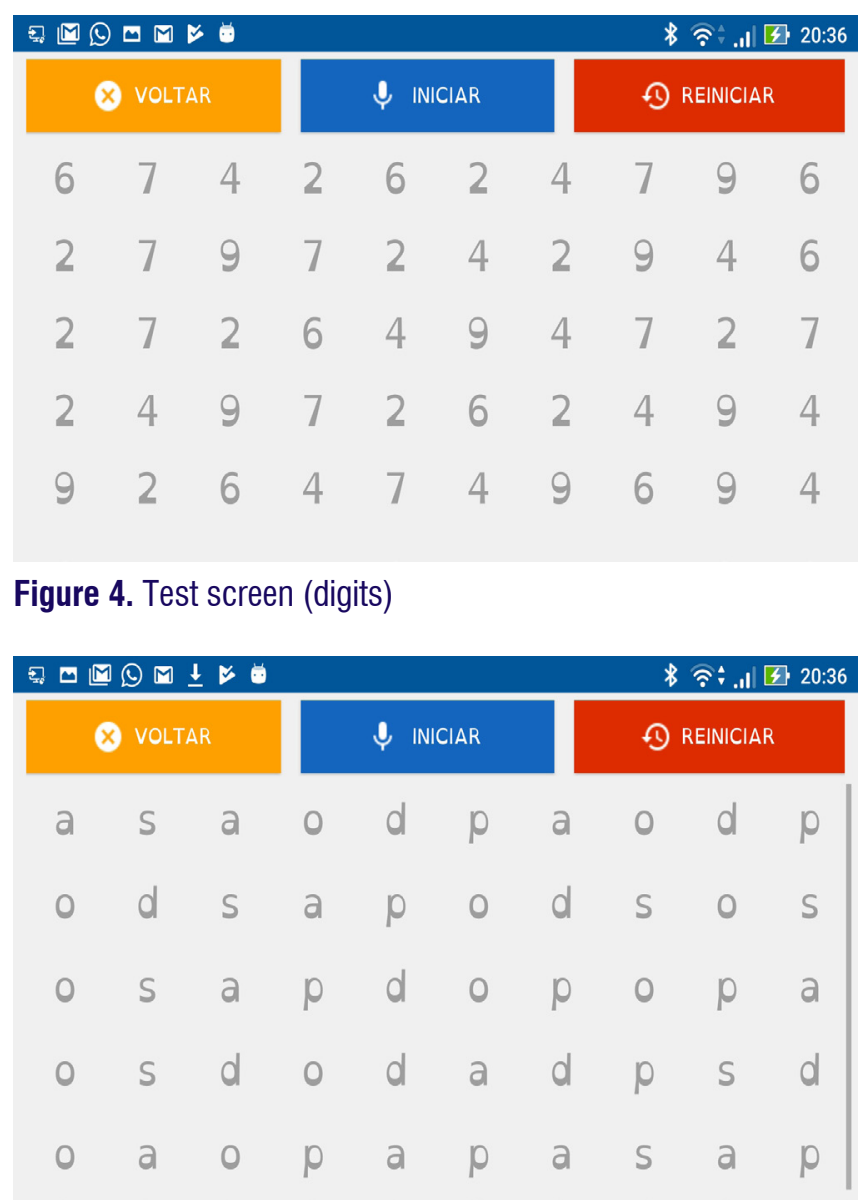

Figure 5. Test screen (letters)

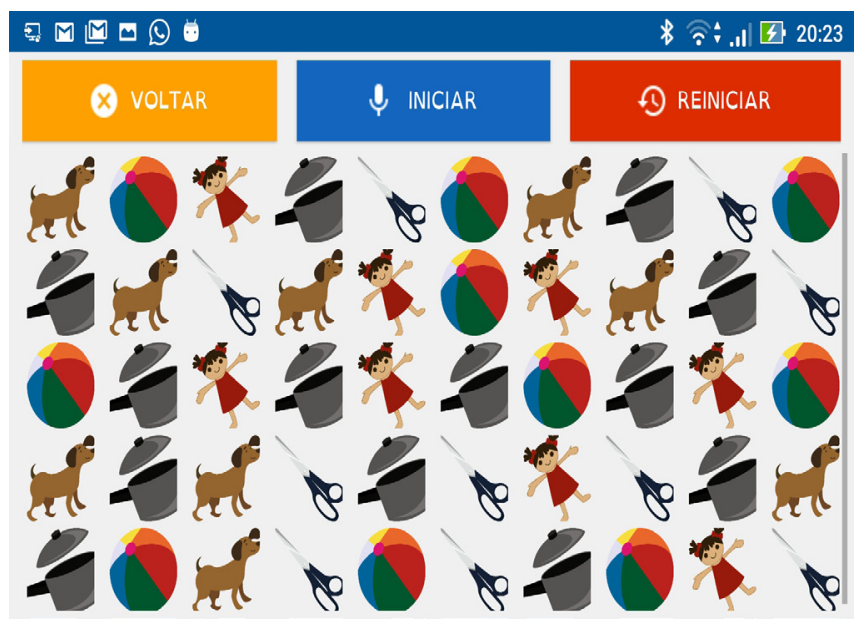

Figure 6. Test screen (objects)

The user can choose the letter font to be used by clicking on the upper right corner of the screen (Figure 7).

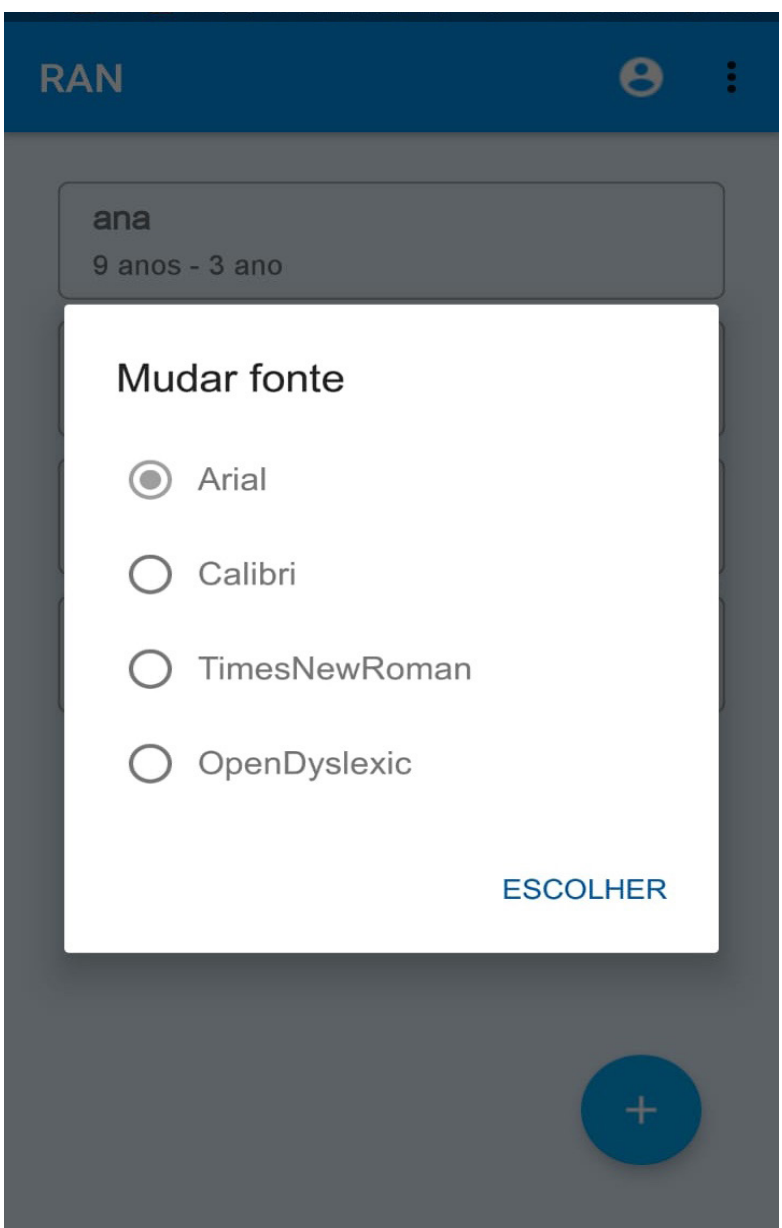

Figure 7. Font selection screen

In any variation of the test, pressing the "start" button starts the test. The naming of the stimuli by the child is captured. The use of voice recognition allows one to count the number of hits and errors, which are displayed on the results screen (Figure 8).

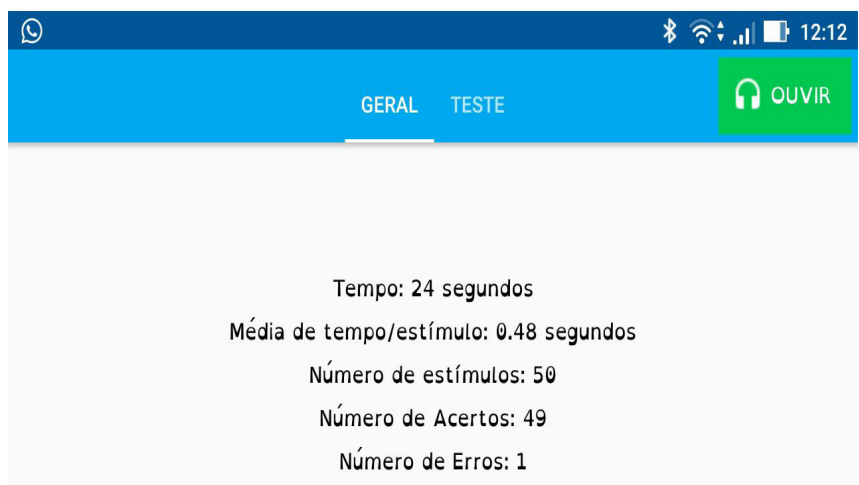

Figure 8. Consolidated results screen 
In addition to the option of the consolidated result, the named stimuli are presented with the indication of hits (indicated with $\square$ ) and errors (indicated with !). The professional examiner able to listen the recorded audio and, therefore, to follow the activity of naming done by the child (Figure 9).

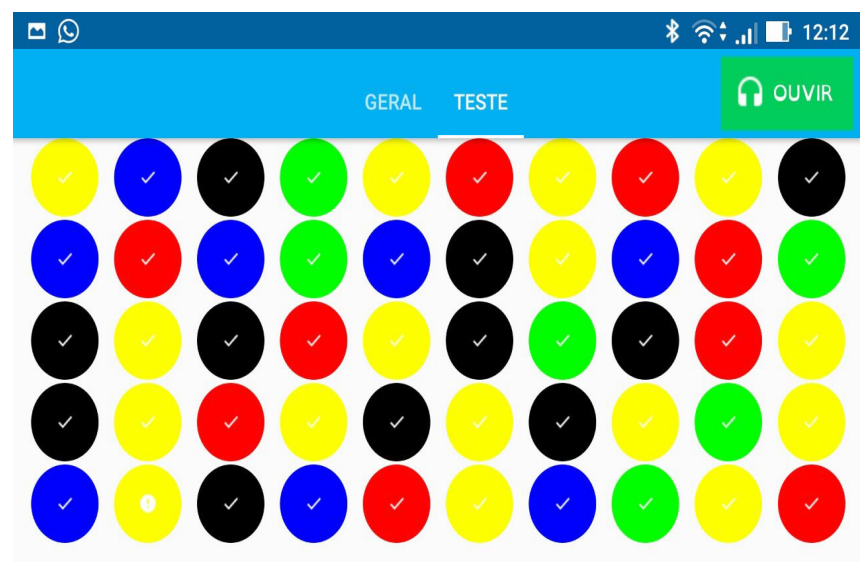

Figure 9. Named stimuli result screen (colors)

The history of the tests performed can be seen by the examiner, allowing him to dispense with the use of cards, in the form of paper. The examiner can therefore monitor the progress of the child.

\section{DISCUSSION}

The RAN test is traditional and widely used in studies involving difficulties in reading in children with and without dyslexia ${ }^{30-36}$. Literature evidences that the slowness in the tasks of the RAN of individuals with dyslexia stems from the fact that when attention and visual recognition need to be coordinated, to then recover a phonological memory (it may be a sound associated with a letter), a strong decrease in the execution speed of tasks occurs. It is precisely the integration between attention and visual recognition and phonological recovery that becomes significantly slow in many children with reading difficulties ${ }^{35,36}$.

The traditional RAN test tasks have been described in the literature using different terms such as rapid serial naming, fast naming, and naming speed. Essentially, a task is categorized as quick-naming if it involves naming familiar stimuli, presented from left to right, in random order, counting the time for naming the stimuli.

In some tasks, the number of hits and errors is also counted for the purpose of qualitative observations regarding the reading fluency of the individual being tested, but the main variable is the time for naming the stimuli ${ }^{17}$.
The test has four variations: colors, letters, digits, and objects ${ }^{17}$. In any of the variations, the child is asked to name, as quickly as possible, 50 visual stimuli on a card or sheet of paper, arranged in five lines containing ten stimuli each, which are randomly presented. The randomness of the distribution of stimuli attends to the condition that no stimulus can be succeeded by itself. The purpose of the test is to name the stimuli one by one as quickly and accurately as possible.

The set of stimuli presented in the sheet or carton is traditionally represented by:

a) Colors: red, yellow, green, blue, and black.

b) Letters: "a", "d”, "o”, "s", and "p".

c) Digits: "2", “4”, “6”, "7", and "9".

d) Objects: umbrella, scissors, comb, watch, and key.

The traditional test involves a series of resources, such as a card and a sheet of paper containing the symbols to be named by the child, a timer to mark the time of the activity, and the professional examiner having to count the number of hits and errors.

Regardless of the variation chosen for the test, traditional or digital, one has as a prerequisite to verify the knowledge that the child has about the stimuli. Usually, 10 sample items are presented to the child before the test, in order to confirm the ability to name them correctly ${ }^{17}$.

Besides the time for naming the stimuli, the numbers of hits and errors serve as a basis for comparative analysis among children of the same age, gender and schooling. Standardized measures are available for individuals aged 5 to 18 years $^{36}$.

To get the impressions of speech therapists and educational professionals about this digital version of the RAN test, a public opinion survey was conducted with unidentified participants through Google Forms. Twenty-one professionals - speech therapists and education professionals - were invited to participate in a public opinion survey without identifying participants through Whatsapp.

By clicking the submitted link, the participant is directed to the Google Forms screen with the guidance of downloading the RAN app on an Android mobile device (Figure 10). Then, after testing the app, the participant should answer the opinion survey and click submit. The participants were instructed not to identify themselves in any of the answers. 


\section{TESTE RAN}

Pesquisa de Opinião - Teste de RAN

\section{BAIXE O APLICATIVO EM SEU APARELHO ANDROID CLICANDO NO LINK \\ ABAIXO:}

https://drive.google.com/ope

n?

id=0ByMmohebvoQ4V2NPNO FDclRkbk0yN1ZDWDRtenpud EVCbEZZ

\section{Você substituiria a versão convencional do teste de RAN pela versão digital ora apresentada?}

Figure 10. Google Forms screen

The public opinion survey was composed of five questions: 1. Would you replace the conventional version of the RAN test with the digital version presented here? (Yes or no); 2. Do you identify elements in the application that make it suitable for the target public of dyslexic children? (Yes or no, if so, cite the elements); 3 . Is the application intuitive? (Yes or no); 4. Do you identify resources in the application that can be used on a daily basis to assist the professional who will apply the test? (Yes or no, if so, please cite the identified resources); 5 . Does the application fulfill its purpose - is it a simple and quick alternative for early detection of reading problems faced by dyslexic children? (Yes or no).

When answering question 1, all participants chose the YES alternative, opting for the digital version of the RAN test.

Responding to 2, all participants identified elements appropriate to the target public, such as: clean screen, soft color set, attractive images and easy handling.

Regarding the application being intuitive (question $3)$, everyone stated that the application has its practical, easy, fast or simple use, highlighting objectivity and practicality as interesting requirements for the tests.

Participants, in answering question 4, cited that one of the utilities of the application is the function of storing the results of the users tested for comparison purposes, to serve as a data source for research, as well as to implement technological tools in clinical practice.

Finally, when answering question 5 , the participants were unanimous in affirming YES - considering the application a simple and fast alternative for the early detection of reading problems faced by dyslexic children.

\section{CONCLUSION}

In the present work, a digital version of the RAN test was presented for mobile devices aimed at the Android platform, targeting children with reading difficulties, with an emphasis on dyslexia.

The developed application presents itself as a useful and dynamic digital tool that assists professionals involved in the field of childhood education to evaluate, early, children with reading difficulties, highlighting the following elements: exclusive images, appropriate to the universe of children, and the storage function of results of tested users.

In further studies, it is important to test the functionality of the application with a greater number of professionals and with children presented with and without dyslexia, as well as compare the results of the application with the printed version of the RAN test.

\section{REFERENCES}

1. Capellini S, Germano G, Cunha VL. Avaliação e intervenção na leitura. In: Capellini S, Germano G, Cunha VL (orgs). Transtornos de aprendizagem e transtornos da atenção: da avaliação à intervenção. São José dos Campos: Pulso Editorial. 2010. p. 49-62.

2. Capellini S, Lanza SC. Desempenho de escolares em consciência fonológica, nomeação rápida, leitura e escrita. Pró-Fono R. Atual. Cient. 2010;22(3):239-44.

3. Alves DS, Soares AJC, Cárnio MS. Velocidade de leitura e nomeação automática rápida em crianças com alterações de leitura e escrita. Distúrb. Comun. 2012;24(2):85-9.

4. Santos AAA, Fernandes ESO. The writing skills and reading comprehension as predictors of school performance. Psicol. Esc. Educ. 2016;20(3):465-73. 
5. Cárnio MS, Vosgrau JS, Soares AJC. The role of phonological awareness in reading comprehension. Rev. CEFAC. 2017;19(5):591-600.

6. Lyon G, Shaywitz S, Shaywitz B. Defining dyslexia, comorbidity, teacher's knowledge of language and reading. Ann of Dyslexia. 2003;53(1):1-14.

7. Shaywitz S, Shaywitz B. Dyslexia (specific reading disability). Biolo Psychiatry. 2005;57(1):18-31.

8. Cardoso-Martins C, Pennington BF. Qual é a contribuição da nomeação seriada rápida para a habilidade de leitura e escrita?: evidência de crianças e adolescentes com e sem dificuldades de leitura. Psicol. Refl. Crít. 2001;14(2):387-97.

9. Howe $\mathrm{AE}$, Arnell KM, Klein RM, Joanisse MF, Tannock R. The ABCs of computized naming: equivalency, reliability and predictive validity of a computerized rapid automatized naming (RAN) task. Journal Neurosci. Methods. 2006;151(1):30-7.

10. Capellini SA, Ferreira TL, Salgado CA, Ciasca SM. Desempenho de escolares bons leitores, com dislexia e com transtorno do deficit de atenção e hiperatividade em nomeação automática rápida. Rev Soc Bras Fonoaudiol. 2007;12(2):114-9.

11. Bicalho LGR, Alves LM. A nomeação seriada rápida em escolares com e sem queixas de problemas de aprendizagem em escola pública e particular. Rev. CEFAC. 2010;12(4):608-16.

12. Araújo GFS, Ferreira TL, Ciasca SM. Rapid automatized naming in 6 and 7 years old students. Rev. CEFAC. 2016;18(2):392-8.

13. Willburger $E$, Fussenegger B, Moll $K$, Wood G, Landerl K. Naming speed in dyslexia and dyscalculia. Learn Individ Differ. 2008;18(1):224-36.

14. Ferreira TL, Capellini SA, Ciasca SM, Tonelloto JMF. Desempenho de escolares leitores profecientes no teste de nomeação automática rápida - RAN. Temas Desenv. 2003;12(69):26-32.

15. Scheltinga $F$, Van der Leij $A$, Van Beinun $F$. Importance of phonological skills and underlying processes to reading achievement: a study on dyslexic and specific language impaired children. IFA Proc. 2003;25(1):21-30.

16. Grigorenko E. Learning disabilities in juvenile offenders, child and adolescent. Psychiatr Clin North Am. 2006;15(2):353-71.

17. Denckla M, Rudel R. Rapid automatized naming (RAN): Dyslexia differentiated from other learning disabilities. Neuropsychology.1976;14(1):471-9.

18. Kirby J. Naming speed and reading: from prediction to instruction. Read Res Q. 2010;45(3);341-62.
19. Cano S, Arteaga J, Collazos C, Zapata S. Towards a methodology for serious games design for children with auditory impairments. IEEE Lat. Am. Trans. 2016;14(5): 2511-21.

20. Oliveira J, Jorge J, Duarte J, Albuquerque V. Complementary treatment for children with cerebral palsy based on virtual reality. IEEE Lat. Am. Trans. 2016;14(8):3820-5.

21. Rybarczyk Y, Gonçalves M. WebLisling: uma plataforma terapêutica baseada na web para a reabilitação de doentes afásicos. IEEE Lat. Am. Trans. 2016;14(8):3921-7.

22. Wire B. Tablet Market Share. [Acesso em: 09.12.2017]. Disponível em: http://www. businesswire.com/news/home/20160801005182/ en/Worldwide-Tablet-Shipments-Decline-12Quarter- Market.

23. IDC: Smartphone Market Share. [Acesso em: 14.11.2017]. Disponível em: http://www.idc.com/ promo/smartphone-market-share/os.

24. OPENDYSLEXIC. [Acesso em 16.11.2017]. Disponível em: https://opendyslexic.org/.

25. Cidrim L, Cajueiro L, Braga P, Bezerra R, Gama C, Madeiro F. DISORTOGRAFANDO: um aplicativo desenvolvido para auxiliar a intervenção com crianças disléxicas. In: Cidrim L, Costa S (orgs). Tecnologias da informação e da comunicação (TIC) aplicadas às ciências da linguagem. Curitiba: CRV. 2015. p. 9-22.

26. Reid G, Strnadova I, Cumming T. Expanding horizons for students with dyslexia in the 21st century: universal design and mobile technology. J Res Spec Educ Needs. 2013;13(3):175-81.

27. Zikl P, Bartosova I, Viskova K, Havlickova K, Kucirkova A, Navrátilova $J$ et al. The possibilities of ICT use for compensation of difficulties with reading in pupils with dyslexia. Procedia Soc Behav Sci. 2015;176(4):915-22.

28. Holz H, Beuttler B, Ninaus M. Design rationales of a mobile game-based intervention for german dyslexic children. In: Annals of Annual Symposium on Computer-Human Interaction in Play. Melbourne: Australia, August 2018.

29. Chase C, Ashourzadeh A, Kelly C, Monfette S, Kinsey $\mathrm{K}$. Can the magnocellular pathway read? Evidence from studies of color. Vision Research. 2003;43(10):1211-22.

30. Albuquerque C, Simões M. Testes de Nomeação Rápida: contributos para a avaliação da linguagem oral. Análise Psicológica. 2009;27(1):65-77. 
31. Capovilla F, Capovilla A. Problemas de aquisição de leitura e escrita: efeitos de deficit de discriminação fonológica, velocidade de processamento e memória fonológica. Revispsi. 2002;2(1):26-50.

32. Alves L, Siqueira C, Ferreira M, Alves J, Lodi D, Bicalho $L$ et al. Rapid naming in Brazilian students with dyslexia and attention deficit hyperactivity disorder. Front. Psychol. 2016;7(21):1-11.

33. Capellini S, Ferreira T, Salgado S, Ciasca S. Desempenho de escolares bons leitores, com dislexia e com transtorno do déficit de atenção e hiperatividade em nomeação automática rápida. Rev Soc Bras Fonoaudiol. 2007;12(2):114-9.

34. Araujo G, Ferreira T, Ciasca S. Rapid automatized naming in 6 and 7 years old students. Rev. CEFAC. 2016;18(2):392-8.

35. Kirby JR, Parrila R, Pfeiffer, SL. Naming speed and phonological awareness as predictors of Reading development. J. Educ. Psychol. 2003;95(3):453-64.

36. Norton E, Wolf M. Rapid automatized naming (RAN) and reading fluency: implications for understanding and treatment of reading disabilities. Annu Rev Psychol. 2012;63(1):427-52. 